\title{
Information sharing protocol
}

The following organisations are parties to this protocol:

The Office for Standards in Education, Children's Services and skills (Ofsted)

The Care Quality Commission (CQC)

Her Majesty's Inspectorate of Constabulary (HMIC)

Her Majesty's Inspectorate of Probation (HMI Prob)

Her Majesty's Inspectorate of Prisons (HMI Pris)

Her Majesty's Crown Prosecution Service Inspectorate (HMCPSI) 
The Office for Standards in Education, Children's Services and Skills (Ofsted) regulates and inspects to achieve excellence in the care of children and young people, and in education and skills for learners of all ages. It regulates and inspects childcare and children's social care, and inspects the Children and Family Court Advisory and Support Service (Cafcass), schools, colleges, initial teacher training, further education and skills, adult and community learning, and education and training in prisons and other secure establishments. It inspects local authority services for children in need of help and protection, looked after children and care leavers. It also inspects Local Safeguarding Children Boards.

If you would like a copy of this document in a different format, such as large print or Braille, please telephone 0300123 1231, or email enquiries@ofsted.gov.uk.

You may reuse this information (not including logos) free of charge in any format or medium, under the terms of the Open Government Licence. To view this licence, visit

www.nationalarchives.gov.uk/doc/open-government-licence/, write to the Information Policy Team, The National Archives, Kew, London TW9 4DU, or email: psi@nationalarchives.gsi.gov.uk.

This publication is available at www.ofsted.gov.uk/resources/140152

Interested in our work? You can subscribe to our website for news, information and updates at www.ofsted.gov.uk/user.

Piccadilly Gate

Store Street

Manchester

M1 2WD

T: 03001231231

Textphone: 01616188524

E: enquiries@ofsted.gov.uk

W: www.ofsted.gov.uk

No. 140152

(C) Crown copyright 2015 


\section{Contents}

Named points of contact 4

Introduction and background $\quad 5$

Sharing inspection reports $\quad 5$

Purpose of sharing the reports 6

Process for sharing, accessing and storing information 6

$\begin{array}{ll}\text { Sharing other information } & 7\end{array}$

$\begin{array}{lr}\text { Legal basis for sharing information } & 8\end{array}$

$\begin{array}{ll}\text { Arrangements to review this protocol } & 9\end{array}$

Signatories to this protocol $\quad 10$

Annex A. List of other memoranda of understanding between the inspectorates

Annex B. Inspection reports shared at the pre-publication stage 


\section{Named points of contact}

\begin{tabular}{|c|c|}
\hline Ofsted & Care Quality Commission \\
\hline Kath O'Dwyer & Lynn Davinson \\
\hline Director of Social Care Inspection and & Children's Services Manager \\
\hline Improvement & Care Quality Commission \\
\hline Ofsted & Children's, Health and Justice Team \\
\hline Piccadilly Gate & Citygate \\
\hline Store Street & Gallowgate \\
\hline Manchester & Newcastle \\
\hline M1 2WD & NE1 4PA \\
\hline $\begin{array}{l}\text { ProtectionOfChildren@ofsted.gov.uk } \\
03001231231\end{array}$ & $\begin{array}{l}\text { childrens-services-inspection@cqc.org.uk } \\
03000616161\end{array}$ \\
\hline $\begin{array}{l}\text { Her Majesty's Inspectorate of } \\
\text { Constabulary }\end{array}$ & $\begin{array}{l}\text { Her Majesty's Inspectorate of } \\
\text { Probation }\end{array}$ \\
\hline Judith Million & Helen Mercer \\
\hline Programme Director & Director (Youth Justice) \\
\hline Protecting Vulnerable People and Joint & HM Inspectorate of Probation \\
\hline Inspection & Post Point 9.54 \\
\hline HMIC & 9th Floor The Tower \\
\hline 5th Floor Globe House & 102 Petty France \\
\hline 89 Eccleston Square & London \\
\hline London & SW1H 9AJ \\
\hline SW1V 1PN & \\
\hline HMICCJJI-PVPProgrammeOffice@hmic.gsi.gov.uk & hmip.enquiries@hmiprobation.gsi.gov.uk \\
\hline 02035130500 & 01612405336 \\
\hline $\begin{array}{l}\text { Her Majesty's Inspectorate of Prisons } \\
\text { Nick Hardwick CBE }\end{array}$ & $\begin{array}{l}\text { Her Majesty's Crown Prosecution } \\
\text { Service Inspectorate }\end{array}$ \\
\hline HM Chief Inspector of Prisons & Jonathan Carver \\
\hline 6th Floor Victory House & Legal Inspector \\
\hline 30-34 Kingsway & HM Crown Prosecution Service Inspectorate \\
\hline London & One Kemble Street \\
\hline WC2B 6EX & London WC2B 4TS \\
\hline hmiprisons.enquiries@hmiprisons.gsi.gov.uk & cjcig@hmcpsi.gov.uk \\
\hline 02036812770 & 02072101169 \\
\hline
\end{tabular}




\section{Introduction and background}

1. This information sharing protocol supplements any existing memoranda of understanding between any of the inspectorates; a list of these can be found at Annex A. ${ }^{1}$ This protocol sets out the circumstances and the mechanisms for how the inspectorates will share information to assist each other in the exercise of their statutory functions.

2. This protocol does not cover any arrangements for sharing information while on inspection as part of any joint multi-agency inspection programme in a local authority area.

3. This arrangement will be in place from 15 May 2015, after which it will be subject to review every three months.

\section{Sharing inspection reports}

4. All parties to this protocol will share the inspection reports listed at Annex B at the pre-publication stage. The pre-publication stage is defined as the point at which the inspection report meets the following criteria:

- the subject of the inspection has had an opportunity to comment on the draft report

- the party who conducted the inspection has finalised the content of the report

- the subject of the inspection has received the final version of the inspection report, under embargo, until the report is published.

5. If, in the course of an inspection, where any party to this protocol identifies concerns that suggest systemic weaknesses in an agency or service provider over which another party has powers of inspection, enforcement or regulation, these concerns will be identified in the pre-publication inspection report. In addition, the relevant Chief Inspector/Executive will write a covering letter to their counterpart/s in the relevant party/parties to highlight the specific systemic concerns identified in the report. This letter will normally be sent with the corresponding pre-publication report.

6. In circumstances, where concerns about practice indicate that children, young people or vulnerable adults are, or may be, at risk of significant harm, any party may decide to send this letter in advance of the report pre-publication

\footnotetext{
${ }^{1}$ This protocol also clarifies paragraph 12 of Ofsted's Framework and evaluation schedule for the inspections of services for children in need of help and protection, children looked after and care leavers and the Review of the Local Safeguarding Children Board; www.gov.uk/government/publications/inspecting-local-authority-childrens-services-framework
} 
stage. In these circumstances the letter will contain information extracted from the record of evidence/draft report for that inspection.

7. Where these concerns relate to a specific individual/s then the parties to this protocol will follow their own procedures for immediately referring the concern to the appropriate protection authorities with the power to act.

8. In all cases, the party that identifies the concerns will notify the service provider to which the concerns relate before informing the other parties.

9. Where required, correspondence must be protectively marked with the appropriate Government Security Classification and include instructions on how the recipient/s should handle the information. ${ }^{2}$

\section{Purpose of sharing the reports}

10. The purpose of sharing the report and, where appropriate, covering letter at the pre-publication stage is to ensure that the parties to this protocol are able to respond promptly to queries that may be received from members of the public, press or other government departments after the reports are published.

11. The purpose of highlighting specifc areas of concern from the report in a cover letter is to alert another party to practice that may leave service users at risk of harm or inappropriately cared for. By alerting the relevant parties to this protocol to the areas of concern they are supported to exercise their powers of inspection, enforcement or regulation in a timescale that most speedily supports the protection and appropriate care of service users.

12. The purpose of sending the letter in advance of pre-publication (where it is determined that there is a risk of significant harm) is to allow the relevant party to take immediate action to ensure that service users are protected.

\section{Process for sharing, accessing and storing information}

13. The inspection reports and covering letters will be sent by email to the points of contact named in this protocol. The parties to this protocol agree that inspection reports are shared under embargo until they are published and the pre-publication stage has ended. During the pre-publication stage, each inspectorate may use their own internal mechanisms for disseminating the inspection reports; however, while under the pre-publication embargo, dissemination of and access to the reports must be limited to:

- Ofsted - members of the social care policy and social care senior management teams. The inspection support management team for local authority social care inspection.

${ }^{2}$ Government security clasifications (2014) Cabinet Office; www.gov.uk/government/publications/government-security-classifications 
- CQC - Children's, Health and Justice Team and senior management in Primary Medical Services and Integrated Care Directorate.

- HMIC - The HMI responsible for Protecting Vulnerable People and Criminal Justice Joint Inspection (PVP/CJJI); the Programme Director for PVP/CJJI and the Head of PVP

- HMI Prob - HMI Probation senior management team

- HMI Pris - The senior management team and members of the inspection support team.

- HMCPSI - The senior management team and legal and business inspectors

14. Versions of the report shared at this stage must be clearly marked as 'Prepublication report - not to be shared beyond authorised reviewers'. Once an inspection report is published, any individual seeking a report should in the first instance be directed to the published version (usually on the relevant party's website) and not provided with the pre-publication version. Prepublication markings will be removed at the point of publication.

15. Reports and letters shared under paragraphs 4-9 of this protocol will not be published, disclosed or shared onwards by the inspectorate receiving that information unless one of the following criteria is met:

- the information is already, lawfully in the public domain (for example, because it has been published by the originating inspectorate)

- there is a legal obligation to disclose (for example, under a court order)

- the originating inspectorate has consented in writing to this.

\section{Sharing other information}

16. To assist a partner inspectorate in the exercise of their statutory functions, there may be occasions where it is desirable to share information other than that gathered through inspection activity related to the reports listed in Annex B. For example, those parties who are also regulators/registration authorities of services and where sharing information would assist the execution of their registration or enforcement activity.

17. The nature of the information shared can vary and may not be known in advance; therefore, it is not feasible to identify in this protocol the precise process for sharing information in all circumstances. The parties to this protocol have agreed that they will consider the information and process for sharing on a case-by-case basis. Any process of sharing will be compliant with any applicable data protection principles, human rights law, duties of confidentiality and any other reasons that are relevant to non-disclosure of information.

18. The parties to this protocol have agreed some illustrative examples where this sharing may occur: 
- In each school term, the inspectorates will share the list of local authority areas in which they plan to conduct inspections in the coming term. This will inform the selection of local authority areas each inspectorate will visit as part of its single agency inspection to ensure all inspectorates' activities are coordinated. Due to the sensitivity of the information, it will be shared through a secure email system or secure online portal.

- Those inspectorates that are also registration authorities will share relevant information, where they are able to do so, to support the inspectorate's assessment of an applicants suitability to be registered. The process for sharing information will be determined on a case-by-case basis according to the content of the information and the purpose of sharing it.

\section{Legal basis for sharing information}

19. Inspectorates are enabled to share information under the following legislation:

- Ofsted: section 149 and paragraphs 6 and 7 of Schedule 13 to the Education and Inspections Act 2006 ('EIA') provide that Her Majesty's Chief Inspector must co-operate with the inspection authorities and may act jointly with another public authority where it is appropriate to do so for the efficient and effective exercise of his functions. Paragraph 8 of Schedule 13 to the EIA provides that Her Majesty's Chief Inspector may provide advice and assistance to another public authority for the purpose of the exercise by that authority of its functions. www.legislation.gov.uk/ukpga/2006/40/contents

- CQC: section 79(3)(e) of the Health and Social Care Act 2008 permits CQC to disclose information where it is necessary or expedient for the recipient to have that information for the purpose of exercising their own statutory functions. Section 79(3)(f) permits CQC to make disclosures for the purpose of facilitating the exercise of its own functions.

www.legislation.gov.uk/ukpga/2008/14/section/79

- HMIC: section 54 of the Police Act 1996 and Schedule 4A, paragaphs 4, 5 and 6. These provisions, in essence, permit HMIC to cooperate with the parties to this protocol, to take joint action with another public authority where it is appropriate to do so for the efficient and effective discharge of their functions, or to assist another public authority for the purposes of the exercise by the authority of its functions. www.legislation.gov.uk/ukpga/1996/16

- HMI Probation: HMI Probation and the office of the Chief Inspector have a statutory basis under section 6 of the Criminal Justice and Court Services Act 2000 (the "2000 Act"). Section 6 of the The 2000 Act provide $s$ the Secretary of State with the power to appoint the Chief Inspector and further inspectors. Section 7 of the 2000 Act introduces Schedule 1A, which makes further provision about the inspectorate. In particular, paragraphs 4, 5 and 6 of Schedule $1 \mathrm{~A}$ provide that HMI Probation must cooperate with other inspection authorities, may act jointly with another public 
authority where it is appropriate to do so for the efficient and effective exercise of his functions and provide assistance, if appropriate, to any other public authority for that authority to exercise its functions. The Offender Management Act 2007 introduced arrangements under which probation services may be provided by providers other than probation boards, so the remit of HMI Probation was amended to reflect those arrangements. www.legislation.gov.uk/ukpga/2000/43/contents

\section{- HM Chief Inspector of Prisons}

- Section 5A of the Prison Act 1952 as amended by section 57 of the Criminal Justice Act 1982, www.legislation.gov.uk/ukpga/1982/48/section/57

- Section 46 (1) of the Immigration, Asylum and Nationality Act 2006 www.legislation.gov.uk/ukpga/2006/13/contents

- The Police and Justice Act 2006 section 28, which added to the 1952 Act by setting out the Chief Inspector's further powers and duties to cooperate and consult with other criminal justice inspectorates and other bodies. www.legislation.gov.uk/ukpga/2006/48/section/28

- HMCPSI: The Police and Justice Act 2006 section 30, which inserts a Schedule to the Crown Prosecution Service Inspectorate Act 2000. This schedule, referenced by section 2 of the 2000 Act, provides the necessary statutory power to exchange information. www.legislation.gov.uk/ukpga/2006/48/section/30

20. All parties to this protocol confirm that their inspection evidence, reports, letters and any processing or sharing of such information will be compliant with the principles within the Data Protection Act 1998.

\section{Arrangements to review this protocol}

21. This information sharing protocol will be reviewed every three months. It will be subject to ongoing review in response to any issues that arise in the intervening periods.

22. A key item to review by Autumn 2015 will be how the inspectorates share information when onsite together for any joint multi-agency inspection .

23. The parties to this protocol agree that they will inform one another if their internal polices for the handling and retention of information change. This is so the potential impact on this protocol can be considered. For queries about each inspectorate's policy on the handling and retention of information, that inspectorate should be contacted. 


\section{Signatories to this protocol}

This signed protocol came into effect on 15 May 2015

\begin{tabular}{|l|l|}
\hline Ofsted & Name of SIRO: \\
\hline Name of head of business area: & $\begin{array}{l}\text { Debbie Jones } \\
\text { National Director, Social Care and Regional } \\
\text { Director, London } \\
\text { Director of Social Care Inspection and } \\
\text { Improvement }\end{array}$ \\
\hline
\end{tabular}

\section{Care Quality Commission}

Name of head of business area:

Name of SIRO:

Sue McMillan

Deputy Chief Inspector of General Practice (North), Children, Health and Justice

Paul Bate

Director of Strategy and Intelligence
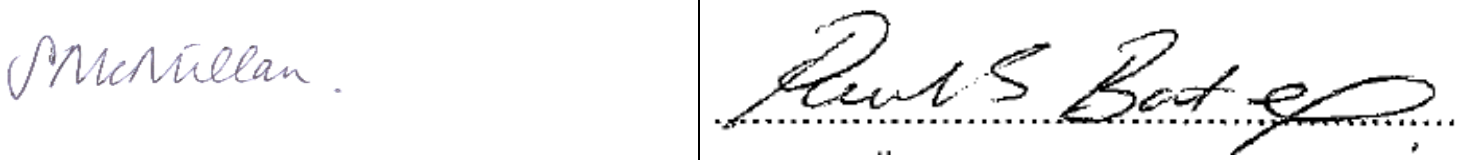

\section{HMI Constabulary}

Name of head of business area:

Name of SIRO:

Judith Million

Programme Director, Protecting Vulnerable

People and Joint Inspection

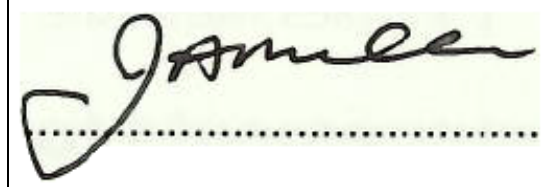

Drusilla Sharpling

Her Majesty's Inspector of Constabulary

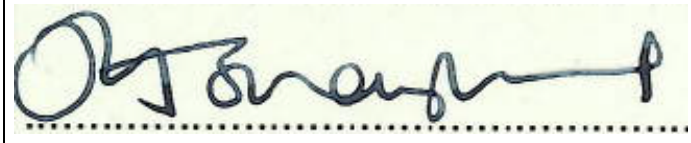




\begin{tabular}{|l|l|}
\hline HMI Probation \\
\hline Name of head of business area: & Name of SIRO: \\
Her Majesty's Chief Inspector of Probation & $\begin{array}{l}\text { Andy Bonny } \\
\text { Director of Support Services }\end{array}$ \\
\hline
\end{tabular}

\begin{tabular}{|l|l|}
\hline HMI Prisons \\
\hline Name of head of business area:
\end{tabular}

\section{HM Crown Prosecution Service Inspectorate}

Name of head of business area:

Michael Fuller

Her Majesty's Chief Inspector

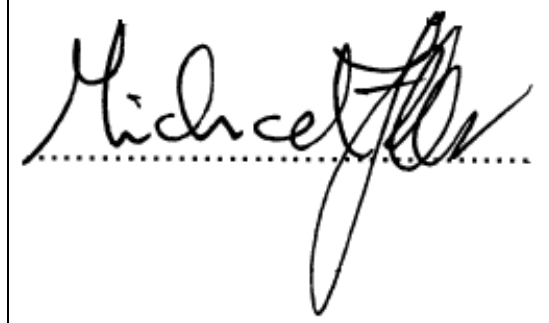

Name of SIRO:

Asker Husain

Her Majesty's Deputy Chief Inspector

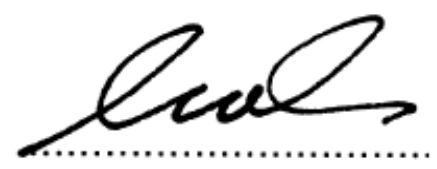




\section{Annex A. List of other memoranda of understanding between the inspectorates}

- The Care Quality Commission and Office for Standards in Education, Children Services and Skills;

www.gov.uk/government/publications/memorandum-of-understandingbetween-ofsted-and-cqc

- The Care Quality Commission and HM Inspectorate of Prisons; www.cqc.org.uk/content/offender-care

- The Care Quality Commission and HM Inspectorate of Probation; www.cqc.org.uk/sites/default/files/documents/20120418_cqc_hmiprobation. pdf 


\section{Annex B. Inspection reports shared at the pre- publication stage}

\section{Ofsted}

- Services for children in need of help and protection, children looked after and care leavers.

- Effectiveness of the local safeguarding children board.

- Any thematic/survey inspection that includes in its scope protection or care of children and young people.

\section{CQC}

- Children Looked After and Safeguarding reports.

- Any single or joint thematic review that includes in its scope the care and protection of children and young people and is relevant to any partner inspectorates.

\section{HMIC}

- Any thematic inspection report that includes in its scope the protection of children and young people.

\section{HMI Probation}

- Inspections of adult offending work where Ofsted have contributed to inspection findings .

- Inspections of youth offending work where Ofsted have contributed to inspection findings.

- Any thematic inspection that includes in its scope protection or care of children and young people.

\section{HMI Prisons}

Any inspections of custody or secure settings holding children.

\section{HMCPSI}

- Single or joint inspections that include in their scope protection or care of children and young people. 